\title{
Information Technology Capability and Performance of Selected Oil and Gas Marketing Companies in Lagos State, Nigeria: The Moderating Role of Organizational Culture
}

\author{
Arokodare, M. A. ${ }^{1}$, Asikhia, O. U. ${ }^{2}, \&$ Makinde, G. O. ${ }^{3}$ \\ ${ }^{1}$ P.hD. Student Department of Business Administration and Marketing, Babcock University, Illishan, Sagamu, \\ Ogun State, Nigeria \\ 2 Professor of Business Administration, Department of Business Administration and Marketing, Babcock \\ University, Illisan-Remo, Ogun State, Nigeria \\ ${ }^{3}$ Lecturer, Department of Business Administration and Marketing, Babcock University, Illisan-Remo, Ogun \\ State, Nigeria \\ Correspondence: Arokodare, M. A., PhD. Student Department of Business Administration and Marketing, \\ Babcock University, Illishan, Sagamu, Ogun State, Nigeria. E-mail: biodunarokodare@yahoo.com
}

Received: October 14, 2019

Accepted: January 5, 2020

Online Published: February 15, 2020

doi:10.5539/ijbm.v15n3p37

URL: https://doi.org/10.5539/ijbm.v15n3p37

\begin{abstract}
Globally, oil and gas marketing companies are in a continuous competitive environment and dilemma of maintaining larger market share among competitors in the oil and gas industry. Most business managers in the oil and gas marketing industry in Nigeria find it difficult in constantly achieving increase in performance in terms of market share due to organisational culture rigidity and poor adoption of information technology capability among oil and gas marketing companies. Hence, this study investigated the relationship between information technology capability and market share as well as the moderating effect of organisational culture on the relationship between information technology capability and performance of oil and gas marketing companies in Lagos State, Nigeria.

The study employed survey research design. The target population comprised 515 oil and gas marketing and retail outlets operating in Lagos State, Nigeria. A total enumeration technique was adopted. Findings revealed that there is a significant and positive relationship between information technology capability and market share and also organisational culture significantly moderate the relationship between information technology capability and market share of oil and gas marketing companies in Lagos State, Nigeria. The study concludes that there is relationship between information technology capability and market share. Also, organisational culture moderates the relationship between information technology capability and market share. It is recommended that oil and gas marketing companies should evolve dynamic business models that will enhance adoption of information technology capability and organisational culture flexibility in order to achieve the advantage of larger market share.
\end{abstract}

Keywords: Information technology capability, Market share, Organisational culture, Oil and gas marketing firms, Nigeria

\section{Introduction}

Organizations around the world especially oil and gas marketing companies, are in a continuous competitive environment and in an unending dilemma of maintaining and increasing market share in the oil and gas industry. Most business managers in the industry find it difficult in constantly achieving targeted market share due to the open market competition and globalisation that characterized the industry. Zafari (2017) has observed that oil and gas marketing companies could not control market share, regardless of whether they be in developed, emerging and developing countries and this is attributed to both natural and technological environments and organisational cultural environments which make it necessary for them to manage business environment dynamics in relation to marketing content and product marketing. Subsequently, global competition and open market policies in the oil and gas industry have led to the downward trend of market share (Zafari, 2017). 
Information Technology (IT) capability is the use of technologies in order to meet the information needs of the company (Turulja \& Bajgoric, 2016). The level of globalisation pressures and rapid technology advances increase the need for firms to continuously adapt, improve, and innovate especially in the oil and gas industry that is susceptible to dynamic policies and shock. The oil and gas marketing firm with greater IT capability and flexible organisational culture will be more successful in responding to changing environments and developing new capacities to achieve better market share performance. In this era of globalisation and intense competition especially in the oil and gas marketing industry, firms without adequate and appropriately relevant IT capability will be carpeted by competitors and will record low market share performance.

In developing countries especially African countries, the outlook for the oil and gas industry is positive amid difficult operating and economic headwinds. Achieving targeted market share has been a major challenge for oil and gas marketing companies in Africa. Information technology incapability has placed considerable pressure on achieving targeted market share of oil and gas marketing companies among the African countries. The challenges facing oil and gas marketing companies in Africa include IT incapability and rigidity in organisational culture to curtail the dynamic nature for which the oil and gas industry is noted for (PricewaterhouseCooper, 2018; Tabe-Khoshnood \& Nematizadeh, 2017). The inability to explore IT practices among Nigerian oil and gas industry has left the industry in a lost market share situation. Specifically in the upstream sector of the industry, the loss for Nigeria has become the gain of other countries, including Ghana, Gabon and Angola, which have become new frontiers for oil exploration in Africa. Oyerinde, Olatunji and Adewale (2018) have further explained that most of oil and gas marketing firms in Nigeria have recorded reduction in market share due to poor IT infrastructural facilities and rigidity of organisational culture towards unstable policies, absence and/or non-implementation of regulations and institutional voids in relation to oil and gas industry.

Considering the problem of reduction in market share in the oil and gas marketing industry in Nigeria, Onigbinde (2014) and Oyerinde et al. (2018) have emphasised that majority of oil and gas marketing firms in Nigeria have recorded a decline in market share due to poor IT strategic response to challenges of regulatory uncertainty and policy instability that characterised the oil and gas marketing industry in Nigeria. Arising from organisational culture rigidity among oil and gas firms in Nigeria, most of these firms cannot easily respond to future and business challenges and uncertain environment surrounding oil and gas industry, thus reduced oil and gas marketing market share in Nigeria. Majority of studies such as (Arokodare, 2019; Chen, Wang, Nevo, Jin, Wang \& Chow, 2014; Kipyegon, Obura \& Oginda, 2018; Lee, Leem \& Bae, 2018; Lu \& Ramamurthy, 2011; Mavengere, 2013; Mao, Liu \& Zhang, 2015; Ockley, Senaji \& Kiyanjui, 2017; Panda \& Rath, 2016; Rahim \& Zainuddin, 2019; Rehman, Mohd Nor, Taha \& Mahmood, 2018; Turulja \& Bajgoric, 2016) have examined how IT capability affects firm performance in different sectors; but most of these studies have never investigated how IT capability affect firm performance proxy with market share of oil and gas marketing companies in Nigeria. Additionally, these past studies have not considered how organisational culture moderates between IT capability and firm performance in terms of market share of oil and gas marketing companies in Nigeria. Considering the problems and gap identified, this study examined (i) the relationship between IT capability and market share of oil and gas marketing companies in Lagos State, Nigeria; and (ii) investigated the moderating role of organisational culture on the relationship between IT capability and market share of oil and gas marketing companies in Lagos State, Nigeria.

\section{Literature Review}

\subsection{Conceptual Review}

\subsubsection{Market Share}

Market share is a company's sales in relation to total industry sales for a certain period (O'Regan, 2002). In this era of intense competition, both international and domestic business firms of all sizes and varieties have become more and more concerned with the market share figures they achieved in the marketplace (Cooper \& Nakanishi, 2014). Increasing market share has become and remained one of the most important organisational objectives and performance measure in today's business world. Essentially, market share is the percentage of consumers that a company has captured from its specific, desired market within an industry. Lancaster and Massingham (2013) have defined market share as a business and market orientation, which focuses company efforts on identifying and satisfying customer needs. Cole (2016) has described market share as the rate of a market either in units or in revenue, accounted for by a specific entity. Market share is calculated on a national level, as well as on more regional and local levels, to determine specific market share. The most basic way of calculating market share is to take the total number of sales for a company and then divide that number by the total sales for the 
industry. Cooper and Nakanishi (2014) have revealed that market shares are used as market performance indices while Doole and Lowe (2016) have argued that it is in the interest of a business organisation that is engaged in production to take its products to the target markets in order to achieve targeted market share. Likewise, Philips, Freeman and Wicks justified the use of market share as a performance measuring metric in order to serve the interests of non-owner stakeholders like employees and customers. However, while Eggers, Kraus, Hughes, Laraway and Snycerski (2013) have been against making market share a basis for making economic policies, Demirel and Mazzucato (2012) have argued that using market share to gauge the performance of competing organisations is useful as it has led organisations to always consider the impact of their decisions on the market share of their competitors. Using market share as a measure of performance of a business firm is simple as it is less dependent on macro environmental variables such as the state of the economy (Arokodare, 2019). Its use also helps managers to evaluate the total market growth or decline and also trends in customers' selections among competitors.

In this study, market share is proxy for firm performance of selected oil and gas marketing companies. The relative performance of oil and gas marketing firms is usually measured in terms of market share within a specified geographical boundary and a time period (Akinyele, 2011). So there is a preponderance of market share as a key performance indicator among these seven firms in Lagos State, Nigeria.

\subsubsection{Information Technology Capability}

Mavengere (2013) has identified Information Technology Capability (ITC) as one of the sub-constructs of the collective capabilities dimension of strategic agility which is the ability of the organisation to successfully utilise its information infrastructure and resources to derive value in order to improve its performance. It is the extent to which a firm is knowledgeable about and effectively utilizes IT to manage information within the firm (Tippins \& Sohi, 2003). Information technology capability has been defined as "the ability of an organisation to acquire, deploy, combine, and reconfigure IT resources to support and enhance business strategies and work processes" (Mao, Liu \& Zhang, 2015: 360). It has been of their opinion that an organisation with the required information infrastructure and resources for its core functions will be able to carry out its functions effectively while possession of such capabilities are important for the organisation to utilise its information resource and promote information management in a competitive business environment.

In Bharadwaj (2000), Chen and Tsou (2012), Gupta, Tan, Ee and Phan (2018) and Liang and You (2009), different aspects of ITC have been examined with the resource-based view which focuses on advantages arising from internal organisational resources that are heterogenous, unique, and difficult to imitate (Barney, 1991). Conversely, some studies have divided IT-based resources into three categories: IT infrastructure, human IT, and IT-enabled intangibles (Bharadwaj, 2000); and Tippins and Sohi (2003) have categorised ITC into IT knowledge (a firm's degree of ownership of a body of technical knowledge), IT operations (a firm's degree of utilisation of IT to manage market and customer information) and IT objects (hardware, software and support personnel). This taxonomy of ITC was later followed by Pebrianto and Djamhur (2013).Though Lu and Ramamurthy (2011) have come up with a multidimensional framework of IT capability as comprising first, IT infrastructure capability, which is the organisation's capability to arrange technical facilities (hardware systems and networks), applications (platforms, databases, operating systems) and IT management services. The second component is IT business spanning capability which is the organisation's capability to integrate IT, business processes, and strategy. It facilitates the ability of organisations to have a clear vision of the value of IT. The third component is IT proactive stance which is the ability of the organisation to proactively explore new IT innovations or exploit available IT resources to create and use business opportunities for competitive advantages. It measures an organisation's attitude towards IT innovations and new IT values ( $\mathrm{Lu}$ and Ramamurthy, 2011). Thus to a business organisation, possession of IT capability is a resource, a strategic asset that when properly put into use, can differentiate the overall performance of one firm from the other (Arokodare, 2019). A key advantage of IT capability in improving organisational performance is that it is an important factor in providing support for organisational learning and means to improve knowledge management in organisations (Pebrianto \& Djamhur, 2013).

\subsubsection{Organizational Culture}

Organisational Culture (OC) is defined as the system of shared assumptions, values, and beliefs that govern how an organisation interacts with both internal and external environments (Stafford \& Miles, 2013). These shared values have a strong influence on how the internal organisational actors interact with others within the environment. Muscalu (2014) has viewed organisational culture as comprising of three key elements: beliefs, behaviours and attitudes. Hayes (2010) has defined organisational culture as "the pattern of basic assumptions 
that are invented, discovered or developed by a group as it learns to cope with its problems of external adaptation and internal integration" (p. 110). Mwangi and Waithaka (2018) have described organisational culture as a relatively uniform perception held of the organisation: it has common characteristics, it is descriptive, it can distinguish one organisation from another, and it integrates individuals, groups, and organisation's system variables. In order to aid long term performance, they have identified three main criteria needed to develop a suitable culture: it must be strategically relevant, it needs to be strong so that people can care about what is important, and the culture must have an ability to adapt to changing circumstances.

Flamholtz and Randle (2011) have identified five key dimensions of organisational culture that must be defined in order for organisational culture to have a positive impact on organisational effectiveness and financial performance. These dimensions include customer orientation or how a firm views its customers, employee orientation or how a firm views its employees, standards of performance and accountability or what and how much employees are held accountable for and how clear and unambiguous the definition of accountability is. The other dimensions are: innovation and commitment to change or how the firm views, embraces, and reacts to change and innovation whether as a core strategy or as an afterthought, and company process orientation or the view of specific aspects of how the firm operates as regards such processes as planning, decision making, communication, and corporate citizenship. The definition of this will depend on the firm size, structure, growth strategy and other relevant factors.

\subsection{Theoretical Foundation}

The theory underpinning this study is the resource-based view.

The Resource-Based View (RBV) which was originated by Barney (1986) and Wernerfelt (1984), was based on the fundamental ideas of Penrose (1959) in the theory of the growth of the firm and Rubin (1973) in the theory of the expansion of firms. The RBV states that organisational resources which are valuable, rare, and difficult to duplicate and substitute are a source of competitive market share advantage, which can improve business performance (Barney, 1991). The RBV of entrepreneurship argues that access to resources by founders is an important predictor of opportunity-based entrepreneurship and new venture growth (Alvarez \& Busenitz, 2001). This theory stresses the importance of information technology as firm resources (Zhou, Zhang, Chen, \& Han, 2017). Thus, access to information technology resources enhances the individual's ability to detect and act upon discovered opportunities, risk taking, and proactiveness, thus increasing firm market share competitive advantage (Davidson \& Honing, 2003).

According to Barney (1991), the RBV rests on three assumptions: that firms seek to earn above average returns; that resources are asymmetrically distributed across competing firms; and that differences in resources lead to differences in product or service characteristics that result in variations in firms' performance. The theory also assumes that individuals are inspired to make maximum use of economic resources available and rational choices that a firm makes which are shaped by economic framework (Barney, 2007). The theory goes beyond the issues of strategy implementation and analysis of organisational processes. These two issues constitute the pre-occupation of most of the earlier works carried out on the strategic implications of the firm's internal environment, which eventually gave rise to strategies (Grant, 2001). The RBV has been criticised because it is static and does not explain how a specific resource can create sustainable competitive advantage while firms do not have enough knowledge about the productivity of each individual asset (Cumberland, 2006). In addition, the concept of firm-specific resources is ambiguous and it is not easy to operationalise measurement items for them (Knott, 2009). The RBV focuses on the role of resources in creating competitive advantage but does not show the relationship between resources and capabilities (Ismail, Rose, Uli, \& Abdullah, 2012).

Many scholars (Alvarez \& Barney, 2007; Barney \& Arikan, 2001; Kumar \& Gulati, 2010; Kuncoro \& Suriani, 2018; Michael, Storey \& Thomas, 2002) have supported the RBV that market share competitive advantage requires four characteristics of resources and capabilities as determinants of the sustainability of market competitive advantage. These are durability, valuable and rare, ease of imitation, transferability and substitutability of firm resources like information technology capability (Grant, 2001). Therefore, this study is anchored on the RBV as its underpinning theory.

\subsection{Empirical Review and Hypothesis Development}

In establishing the relationship between IT capability and firm market share, and determining the moderating role of organisational culture, many studies within and outside Nigerian context were empirically reviewed. Most empirical findings as regards the interaction between IT capability, market share and organisational culture have been mixed. Some studies exert positive relationship while others exert negative relationship and this mixed result was due to the high level of competition and pattern of organisational culture of different 
organisations in different industries. The studies of AlBar and Hoque (2017), Alis, Jabeen and Nikhitha (2016), Chen and Kamal (2016), Chege, Wang and Suntu (2019), Macharia, Mike, Ondabu and Kepha (2015) and Turulja and Bajgorić (2016) have empirically found that IT capability has positive and significant effect on firm performance. Furthermore, Amali, Hadjaratie and Suhada (2018) and Salehzadeh, Pooll, Mohseni and Tahani (2017) have established that the importance of organisational culture towards the application of IT governance can decide a suitable model of development with the organisational goals and overall performance. Oliveira (2017) has also established that the role of organisational culture is crucial for the leader, as one key factor of success in IT governance, in formulating harmonious strategies of IT utilization policy with business strategy in order to achieve targeted overall performance. Aasi, Rusu and Han (2016) have found that cultural types have an effect on the profitability measures of organisational performance and this reinforces the relationship between organisational culture and organisational performance. Similarly, studies such as Ahmed and Shafiq (2014) and Napitupulu (2018) have empirically revealed that organisational culture is a critical and significant supporting factor for organisational performance. Ahmed and Shafiq (2014) have found out that organisational culture affects organisational performance and plays an important role in achieving organisational objective of franchise telecom companies in Bahawalpur, Pakistan. Similarly, Onobrakpeya, Nana and Odu (2018) have found that electronic mail, teleconferencing and telecommuting as variables of information and communication technology have a positive effect on service delivery.

Considering several empirical studies reviewed, most of these studies have not investigated how organisational culture moderates the relationship between information technology capability and market share of oil and gas marketing companies, thus indicating an empirical gap which this study intends to fill. Based on the empirical gap identified on the moderating role of organisational culture between IT capability and market share performance of oil and gas marketing firms, this study therefore hypothesised that:

(i) $\mathbf{H}_{01}$ : There is no significant relationship between IT capability and market share of oil and gas marketing companies in Lagos State, Nigeria.

(ii) $\mathbf{H}_{02}$ : Organisational culture has no significant moderating effect on the relationship between IT capability and market share of oil and gas marketing companies in Lagos State, Nigeria.

\subsection{Conceptual Model}

The researchers' conceptual model in figure 1 depicted the relationship between information technology capability and firm market share and also how organisational culture moderates the relationship between information technology capability and market share of oil and gas marketing companies. The researchers' conceptual model was anchored on RBV which shows how firms use IT capability and organisational culture as resources to create and sustain market share performance over other firms without IT capability. The RBV states that firms' resources could be information technology capability, and organisational culture in which for firms to gain market share competitive advantage, there must be employment and adoption of incomparable information technology capability, and flexible organisational culture as firm resources so as to achieve market competitive advantage. Ahmed and Shafiq (2014) and Napitupulu (2018) have emphasised that in today's globalisation and boundryless trade, firm with advance information technology capability and flexible organisational culture resources will outperform firms with no information technology resource. Based on the RBV assertion on firm resources and market competitive advantage, a researchers' conceptual model was formulated in figure 1.

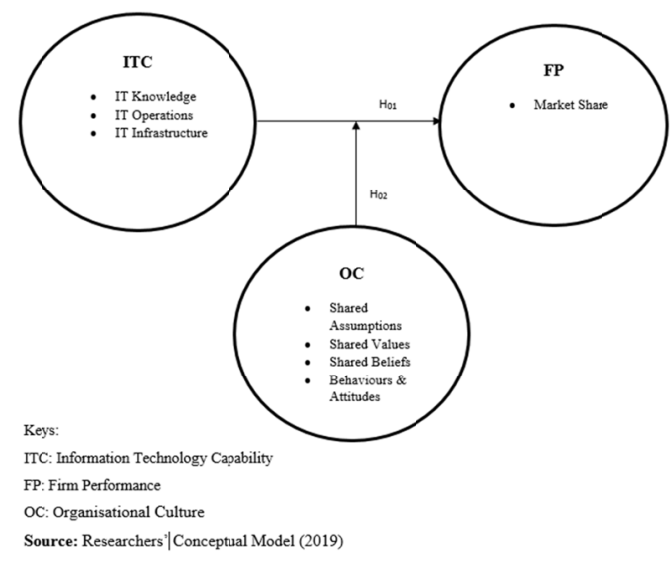

Figure 1. Conceptual Model 
The resource-based view of IT capability suggests that firms can differentiate themselves from competitors by means of their IT resources (Chen \& Tsou, 2012). On the other hand, while it is difficult to acquire or imitate each distinct IT resources, firms can also achieve competitive advantage through learning to combine their existing IT resources more effectively (Bharadwaj, 2000). Information technology resources encompass IT infrastructure, human skills in working with IT, and the organisation's ability to manipulate IT, which combine to form an intangible resource called IT capabilities (Bharadwaj, 2000). This view of IT resources has received much support in the IT literature where IT capability is the ability to manage these three IT resources and the combination of these resources is a competitive advantage (Mazidi, Amini \& Latifi, 2014). In the process, the firms that are able to manage these IT resources efficiently do ultimately increase their market share. Therefore, a firm is successful not only because it has implemented a cutting-edge IT application but also because it has developed a capability for applying IT to changing its business opportunities (Li, Chen \& Huang, 2006). When every leading organisation across most industries and businesses has access to the same IT capability resources, then what will determine the competitive advantage of these firms will be the way these IT capability resources are managed. This was confirmed in Sampath (2015), where it was found that any advantage derived from technology was short-lived but what differentiated the firms was how they used technology to meet customer expectations.

An organisational culture can be strong or weak depending on the width and depth of the intensity of specific shared values (Flamholtz \& Randle, 2011). They posited that in a strong culture, the organisational culture is clearly defined, reinforced with good communication, and all employees behave in ways consistent with the defined culture. When organisational culture acts as a weakness, it may delay, obstruct, or prevent the smooth implementation of a strategy by creating or promoting resistance to change (Araujo \& Sampaio, 2014). Thus strategic options of the organisation, like introducing or expanding the scope of IT, can be limited by the culture of the organisation (Schein, 2004). According to Kotter (2012), organisational culture has the potential to enhance the performance of any institution and the sense of certainty about problem solving. Uzkurt, Kumar, Semih Kimzan and Eminoglu (2013) have indicated that to be competitive and responsive to environmental changes, mechanisms must be put in place to foster and encourage an innovative culture in the organisations in order to facilitate the introduction, adoption and diffusion of innovations which in turn will result in achievement of superior firm performance.

\section{Methodology}

This study employed survey research design to obtain field information on study variables in examining the moderating role of organisational culture on the relationship between IT capability and market share of selected oil and gas marketing firms in Lagos State, Nigeria. This research considered the 515 retail filling stations owned and/or operated by NNPC Retail Ltd (NRL) and the other major petroleum products marketers (Conoil Plc, 11 Plc, Forte Oil Plc, MRS Oil Nigeria Plc, OVH Energy Marketing Ltd and Total Nigeria Plc) as the adjusted population of the study. The sample frame was the list of depot managers/station managers of selected oil and gas marketing companies in Lagos State drawn from DPR Annual Report (2017). Depot/station managers were used because they have knowledge and experience about the strategic operations, strategic policies and decision-making processes of the retail/depot stations. Lagos State was chosen because it hosts the second highest number of retail outlets and also serves as the commercial hub in the country. Hence, a total enumeration method was adopted since the population of this study is small. Primary source of data was used through questionnaire in gathering data from the respondents. Pearson correlation method of analysis was employed for hypothesis one while hierarchical regression method of analysis was employed for hypothesis two.

The questionnaire used was validated and the reliability of the study variables was established. The reliability of the research instrument was ascertained based on the Cronbach Alpha measure of reliability which is greater than 0.7. In this study, market share is the dependent variable and IT capability serves as the independent variable while organisational culture is the moderating variable. For dependent, independent and moderating variables, a six-point modified Likert scale type was used to elicit responses from every question in the questionnaire and this covered; Very High $(\mathrm{VH})-6$; High $(\mathrm{H})-5$; Moderately High $(\mathrm{MH})-4$; Moderately Low (ML) - 3; Low (L) - 2; Very Low (VL) - 1. For the dependent variable: Decrease Greatly (DG) -6; Little Decrease (LD) -5; Almost the Same (AS) -4; The Same (TS) -3; Little Increase (LI) -2; and Increase Greatly (IG) $-1$. 


\subsection{The Validity and Reliability Result}

Table 1. KMO, Bartlett's test of sphericity and reliability result

\begin{tabular}{|c|c|c|c|c|c|c|}
\hline Variables & $\begin{array}{ll}\text { Number } & \text { of } \\
\text { Questions } & \\
\end{array}$ & KMO & $\begin{array}{lll}\text { Bartlett test of } \\
\text { Sphericity }\end{array}$ & $\begin{array}{l}\text { Cronbach's } \\
\text { Alpha }\end{array}$ & $\begin{array}{l}\text { Average } \\
\text { Explained }\end{array}$ & Variance \\
\hline Market Share & 8 & 0.643 & 0.002 & 0.734 & 0.832 & \\
\hline $\begin{array}{l}\text { Information } \\
\text { Capability }\end{array}$ & 5 & 0.716 & 0.000 & 0.805 & 0.786 & \\
\hline Organisational Culture & 11 & 0.526 & 0.006 & 0.874 & 0.743 & \\
\hline
\end{tabular}

Source: Researchers' Computation (2019).

The result in Table 1 shows that the KMO is greater than 0.5 . It means that the questions actually measure the variables in the study. The result of the Bartlett test of Sphericity at 0.000 which is less than $5 \%$, indicate that there is highly significant relationship among variables in measuring the variables under study. In this study, the KMO test is greater than $5 \%$ and Bartlett test of Sphericity result is less than $5 \%$ indicating that statements that comprised the research instruments of each variable actually measured what were intended to be measured. The result of the KMO and Bartlett test of Sphericity are shown in Table 3.1. The construct validity of the research instrument was further established through confirmatory factor analysis. Average Variance Extracted (AVE) greater than 0.5 was used as an additional evidence of construct validity of all variables in the research instrument. The result of the Cronbach Alpha was greater than 0.70 for each of the variables which indicated that the items used to measure study variables were reliable. The Pearson correlation method of analysis was used to determine the relationship between IT capability and market share of the oil and gas marketing firms while the hierarchical regression method of analysis was employed to examine the moderating role of organisational culture on the relationship between IT capability and market share of these firms.

\subsection{Model Specification}

In this study, the dependent variable was firm performance proxy with market share; the independent variable is IT capability while the moderating variable is organisational culture. The model for the study was denoted as;

$\mathrm{Y}=$ Dependent Variable $=$ Firm Performance proxy by Market Share (MS)

$\mathrm{X}=$ Independent Variable $=$ IT Capability (ITC)

$\mathrm{Z}=$ Moderating Variable $=$ Organisational Culture $(\mathrm{OC})$

The model formulated for each of the hypothesis will be functionally written as:

$$
\mathrm{Y}=\mathrm{f}(\mathrm{X})
$$

Hypothesis 1

$\mathrm{Y}=\mathrm{f}(\mathrm{XZ})$

$\mathrm{Y}=\beta_{0}+\beta_{\mathrm{i}} \mathrm{X}_{\mathrm{i}}+\beta_{\mathrm{z}} \mathrm{Z}+\beta_{\mathrm{iz}} \mathrm{XZ}+\varepsilon_{\mathrm{i}}$

$$
\mathrm{MS}=\beta_{0}+\beta_{\mathrm{i}} \mathrm{ITC}_{\mathrm{i}}+\beta_{\mathrm{z}} \mathrm{OC}+\beta_{\mathrm{iz}} \mathrm{ITC}^{*} \mathrm{OC}_{\mathrm{i}}+\varepsilon_{\mathrm{i}}
$$

$\beta_{0=}$ the constant term; $\beta_{\mathrm{i}}=$ the regression coefficient for ITC; $\beta_{\mathrm{z}}=$ the regression coefficient for OC while $\beta_{\mathrm{iz}}$ is the regression coefficient for both ITC and OC and lastly, $\varepsilon_{i}=$ Error Term.

\section{Result and Discussions}

Table 2. Correlation Results for Information Technology Capability (ITC) and Market Share (MS)

\begin{tabular}{llll}
\cline { 2 - 4 } & Variables & MS & ITC \\
\cline { 2 - 4 } & MS & 1 & \\
ITC & $0.651^{* *}$ & 1 \\
\hline
\end{tabular}

**. Correlation is significant at the 0.05 level (2-tailed).

Source: Researcher's Field Survey Result (2019).

Table 2 gives the Pearson (r) correlation coefficient values as well as the P-values of significance showing the degree and significance of the relationship between market share and information technology capability. Table 2 
shows a positive and significant $(\mathrm{r}=0.651, \mathrm{p}<0.05)$ correlation between market share and information technology capability of oil and gas companies in Lagos State, Nigeria. This means that increase in information technology capability will lead to the increased market share of oil and gas marketing companies in Lagos State, Nigeria. Considering this result, the null hypothesis $\left(H_{01}\right)$ which states that there is no relationship between information technology capability and market share of selected oil and gas marketing companies in Lagos State, Nigeria was rejected.

Table 3. Model Summary for moderating effect of organisational culture on the relationship between information technology capability and market share

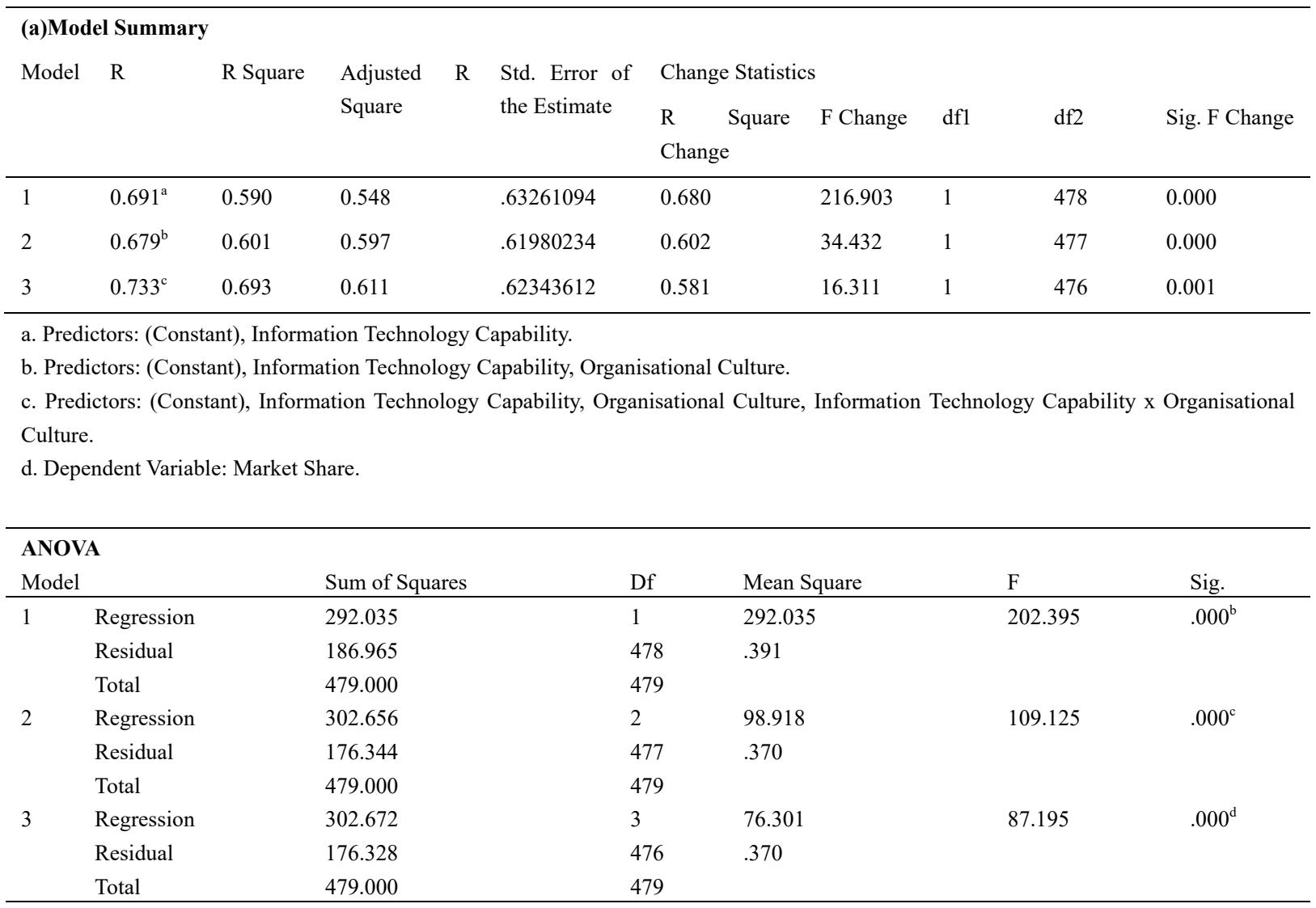

a. Dependent Variable: Market Share.

b. Predictors: (Constant), Information Technology Capability.

c. Predictors: (Constant), Information Technology Capability, Organisational Culture.

d. Predictors: (Constant), Information Technology Capability, Organisational Culture, Information Technology Capability x Organisational Culture.

Source: Researchers' Results (2019).

Tables 3 presents hierarchical multiple regression results for the moderating effect of organisational culture on the relationship between Information IT capability and market share. Results in Table 3 summarise the output for the analysis if moderation effect is not considered. Therefore, in this model, the independent variable was Information Technology Capability. From Table 3, Model 1 reveals that $\mathrm{R}=0.691, \mathrm{R}^{2}=0.590$ and $[\mathrm{F}(1,478)=$ $216.903, \mathrm{p}=.0000]$. The value of coefficient of determination, $\mathrm{R}^{2}$ indicates that $59 \%$ of the variance in the market share of selected oil and gas marketing companies in Lagos State was accounted for by IT capability. The remaining $41 \%$ of the total variation in market share are explained by factors not included in the model. The adjusted R-squared value was found to be 0.548. After considering the moderator, the adjusted R-square value was $0.611(61.1 \%)$ and the explained variation in the relationship of study variables was found to be significant $(\mathrm{p}=0.001<0.05)$. In Table 3, the F-statistics is 87.195 with a corresponding $p$-value of 0.000 ( $p$-value $<0.05)$ indicating that organisational culture significantly moderate the relationship between information technology capability and market share of selected oil and gas marketing companies in Lagos State. Based on these results (i) 
the null hypothesis $\left(H_{01}\right)$ which states that there is no relationship between information technology capability and market share of selected oil and gas marketing companies in Lagos State, Nigeria was rejected; and (ii) the null hypothesis $\left(H_{02}\right)$ which states that organisational culture has no significant moderating effect on the relationship between information technology capability and market share of selected oil and gas marketing companies in Lagos State, Nigeria was rejected.

Various studies have supported findings of this study that IT capability has a positive relationship with firm market share and that organisational culture moderated the relationship between IT capability and performance indicator like market share especially in today's dynamic business environment (See Chege, Wang \& Suntu, 2019; Macharia, Mike, Ondabu \& Kepha, 2015; Turulja \& Bajgorić, 2016). Further majority of scholars in different economies strongly have established that organisational culture and information technology capability were major determinants of firm overall performance due to the continuous pace of globalisation and dynamics that characterised 21st century business environment (Djaja \& Arief, 2015; Kipyegon, Obura \& Oginda, 2018; Lee, Leem \& Bae, 2018; Lu \& Ramamurthy, 2011; Mavengere, 2013; Mao, Liu \& Zhang, 2015; Ockley, Senaji \& Kiyanjui, 2017). Salehzadeh, Pool, Mohseni and Tahani (2017) have showed that organisations must pay adequate attention to the development of an effective organisational culture, and facilitating the process of knowledge sharing and organisational agility which can lead to increased organisational performance. An earlier study, AbdulRashid, Sambasivan and Johari (2003) have found that organisational culture could also enhance the level of organisational commitment and thereby ensure organisational success. This includes commitment to IT capability of the organisation. Based on the majority support for the findings of this study, (i) the null hypothesis $\left(\mathbf{H}_{01}\right)$ which states that there is no relationship between information technology capability and market share of selected oil and gas marketing companies in Lagos State, Nigeria was rejected (ii) the null hypothesis $\left(\mathbf{H}_{\mathbf{0 2}}\right)$ that organisational culture does not moderate the relationship between information technology capability and market share was rejected.

\section{Conclusion and Managerial Implication}

Based on the findings of this study, it is concluded that information technology capability has significant relationship with market share of oil and gas marketing companies in Lagos State, Nigeria. Also, organisational culture significantly moderates the relationship between information technology capability and market share of selected oil and gas marketing firms in Lagos State, Nigeria.

Considering the findings, the study recommends that: oil and gas marketing companies should embrace a proactive approach to the investment in, and the implementation and maintenance of IT capabilities so as to achieve market competitive edge over players in the industry. Similarly, oil and gas marketing companies should be market oriented in order to understand customer reaction towards their service delivery, product prices and operations as this will enable them gain more market share over competitors. Specifically, the ability of these firms to be strategically agile by being sensitive to changes in the environment and responding at fast speeds to such changes will be enhanced by a conscious and an upscale investment in IT capability coupled with a rapid orchestration process in the utilisation of that capability. Furthermore, managers should put an emphasis on building up their IT capability as a precursor of a more holistic capabilities development in their organisations. Additionally, for an oil and gas marketing firm to control a larger market share among its competitors in the industry, it is important for the firm to fully adopt and employ information technology capability so as to achieve market share control and also evolve dynamic business models that will enhance adoption of information technology capability and organisational culture flexibility in order to achieve market share competitive advantage over other players in the oil and gas marketing industry. Lastly, managers should incorporate mechanisms that will foster and encourage an innovative culture in their organisations in order to facilitate the introduction, adoption and diffusion of innovations which in turn will result in achievement of superior firm performance and ultimately an increased market share. These innovations include investments in and adoption of IT capability.

\section{Limitation of the Study and Suggestions for Further Study}

This study was limited to oil and gas marketing companies, therefore, the findings of the study cannot be generalized for making decisions in other industries. Also, access to specific information and data were curtailed and possible reasons for this could be the feeling of divulging the information to competitors in the same industry. The study suggested that further study should: (i) employ study variables to carry out a comparative analysis between NNPC retail outlets, major marketers and independent marketers so as to analyse the market competition trend between all the major players in the oil and gas marketing industry; (ii) examine how organisational culture moderates the relationship between information technology capability and market share in 
the upstream of oil and gas industry; and also, (iii) further study should examine how price shocks or other external factors moderate the relationship between information technology capability and market share of oil and gas marketing companies in Nigeria.

\section{References}

Aasi, P., Rusu, L., \& Han, S. (2016). The influence of organisational culture on it governance performance: Case of the IT department in a large Swedish company. In Proceedings of Hawaiian International Conference in Systems Sciences 2016 (HICSS 49, pp. 5157-5166). IEEE Computer Society,

Abdul-Rashid, Z., Sambasivan, M., \& Johari, J. (2003). The influence of corporate culture and organisational commitment on performance. Journal of Management Development, 22(8), 708-728. http://dx.doi.org/10.1108/02621710310487873

Akinyele, S. T. (2011). Strategic marketing and firm performance: A study of Nigerian oil and gas industry. Business Intelligence Journal, 4(2), 303-311.

Ahmed, M., \& Shafiq, S. (2014). The impact of organisational culture on organisational performance: A case study on telecom sector. Global Journal of Management and Business Research: A (Administration and Management), 14(3-I),20-30.

AlBar, A. M., \& Hoque, R. (2017). Factors affecting the adoption of information and communication technology in small and medium enterprises: A perspective from rural Saudi Arabia. Information Technology for Development, 14(6), 1-24. http://dx.doi.org/10.1080/02681102.2017.1390437.

Alis, S., Jabeen, U. A., \& Nikhitha, M. (2016). Impact of ICTs on agricultural productivity. European Journal of Business Economics and Accountancy, 4(5), 82-92.

Alvarez, S. A. \& Barney, J. B. (2007). Discovery and creation: Alternative theories of entrepreneurial action. Strategic Entrepreneurship Journal, 1(1-2), 11-26. https://oi.org/10.1002/sej.4

Alvarez, S. A., \& Busenitz, L. W. (2001). The entrepreneurship of resource-based theory. Journal of Management, 27(6), 755-775. https://doi.org/10.1177/014920630102700609

Amali, L. M., Hadjaratie, L., \& Suhada, S. (2018). The influence of organisational culture in application of information technology governance. Journal of Information Systems Engineering and Business Intelligence, $4(1), 1-10$

Araújo, M., \& Sampaio, P. (2014). The path to excellence of the Portuguese organisations recognised by the European foundation for quality management model. Total Quality Management \& Business Excellence, 25(5-6), 427-438. https://doi.org/10.1080/14783363.2013.850810

Arokodare, M.A. (2019). Strategic agility and firm performance of selected oil and gas marketing companies in Lagos State, Nigeria. (Unpublished Doctoral Thesis). Babcock University, Nigeria.

Barney, J. B. (1986). Organisational culture: Can it be a source of sustained competitive advantage? Academy of Management Review, 11(3), 656-665. https://doi.org/10.5465/amr.1986.4306261

Barney, J. B. (1991). Firm resources and sustained competitive advantage. Journal of Management, 17, 99-120. https://doi.org/10.1177/01492063910170018

Barney, J. B. (2007). The resource-based view of strategy: Origins, implications, and prospects. Editor of Special Theory Forum in Journal of Management, 17, 97-211.

Barney, J. B., \& Arikan, A. M. (2001). The resource-based view: Origins and implications. In M. A. Hitt, R. F. Freeman, \& J. S. Harrison (Eds.), Handbook of Strategic Management (124-188). Oxford: Blackwell Publisher.

Bharadwaj, A. S. (2000). A resource-based perspective on information technology capability and firm performance: An empirical investigation. MIS Quarterly, 169-196. https://doi.org/10.2307/3250983

Chege, S. M., Wang, D., \& Suntu, S. L. (2019). Impact of information technology innovation on firm performance in Kenya. Information Technology for Development, 1-30. https://doi.org/10.1080/02681102.2019.1573717

Chen, W., \& Kamal, F. (2016). The impact of information and communication technology adoption on multinational firm boundary decisions. Journal of International Business Studies, 47, 563-576.

Chen, J. S., \& Tsou, H. T. (2012). Performance effects of IT capability, service process innovation, and the mediating role of customer service. Journal of Engineering and Technology Management, 29(1), 71-94. 
https://doi.org/10.1016/j.jengtecman.2011.09.007

Chen, Y., Wang, Y., Nevo, S., Jin, J., Wang, L., \& Chow, W. S. (2014). Information technology capability and organisational performance: The roles of business process agility and environmental factors. European Journal of Information Systems, 23(3), 326-342.

Cole, R. A. (2016). Do banks or VCs spur small firm growth? Journal of International Financial Markets, Institutions and Money, 41, 60-72. https://doi.org/10.1016/j.intfin.2015.12.005.

Cooper, Y., \& Nakanishi, D. (2014). Implementing strategic missions: Effective strategic, structural and tactical $\begin{array}{lllll}\text { choices. Journal of } & \text { Management }\end{array}$ https://doi.org/10.1111/j.1467-6486.1994.tb00627.x

Cumberland, F. (2006). Theory development within international market entry mode: An assessment. The Marketing Review, 6(4), 349-373.

Davidson, P., \& Honing, B. (2003). The role of social and human capital among nascent entrepreneurs. Journal of Business Venturing, 18, 301-331.

Demirel, P., \& Mazzucato, M. (2012). Innovation and firm growth: Is R\&D worth it? Industry and Innovation, 19(1), 45-62. https://doi.org/10.1080/13662716.2012.649057

Department of Petroleum Resources (2017). Nigeria Oil and Gas Industry Annual Reports. Lagos, Nigeria: $\begin{array}{lllll}\text { Department of Petroleum } & \text { Resources. } & \text { Retrieved }\end{array}$ https://www.dpr.gov.ng/wp-content/uploads/2018/10/2017-NOGIAR-WEB.pdf

Djaja, I., \& Arief, M. (2015). The impact of dynamic information technology capability and strategic agility on business model innovation and firm performance on ICT firms. Advanced Science Letters, 21(5), 1225-1229. https://doi.org/10.1166/asl.2015.6105 1225

Doole, I., \& Lowe, R. (2016). International marketing strategy: Analysis, development and implementation. London: Thomson Learning.

Eggers, F., Kraus, S., Hughes, M., Laraway, S., \& Snycerski, S. (2013). Implications of customer and entrepreneurial orientations for SME growth. Management Decision, 51(3), 524-549. http://dx.doi.org/10.1108/00251741311309643

Flamholtz, E., \& Randle, Y. (2011). Corporate culture: The ultimate strategic asset. Stanford University Press.

Grant, R. M. (2001). Knowledge and organisation. In Nonaka, I., \& Teece, D. J. (Eds.), Managing Industrial Knowledge: Creation, Transfer and Utilization (pp. 145-169). London: Sage.

Gupta, G., Tan, K.T., Seng, E.Y., \& Phang, C.S. (2018). Resource-based view of information systems: Sustainable and transient competitive advantage perspectives. Australasian Journal of Information Systems, 22, 1-10. https://doi.org/10.3127/ajis.v22i0.1657

Hayes, J. (2010). The theory and practice of change management (3rd ed). United Kingdom: Palgrave Macmillan.

Ismail, A. I., Rose, R. C., Uli, J., \& Abdullah, H. (2012). The relationship between organisational resources, capabilities, systems and competitive advantage. Asian Academy of Management Journal, 17(1), 151-173.

Kipyegon, B. A., Obura, J., \& Oginda, M. (2018). Analysis of information systems capabilities and performance of firms in telecommunications industry, Kenya. International Journal of Scientific Research and Management, 6(4), 319-327.

Knott, P. (2009). Integrating resource-based theory in a practice-relevant form. Journal of Strategy and Management, 2(2), 163-174. https://doi.org/10.1108/17554250910965317

Kotter, J. P. (2012). Leading change. Boston, MA: Harvard Business Press.

Kumar, S., \& Gulati, R. (2010). Dynamics of cost efficiency in Indian public sector banks: A post-deregulation experience. In Twelfth Annual Conference on Money and Finance in the Indian Economy, March, Mumbai.

Kuncoro, W., \& Suriani, W. O. (2018). Achieving sustainable competitive advantage through product innovation and market driving. Asia Pacific Management Review, 23(3), 186-192. https://doi.org/10.1016/j.apmrv.2017.07.006

Lancaster, B. N., \& Massingham, J. (2013). Achieving optimal business performance through business practices: 
Evidence from SMEs in selected areas in South Africa. Southern African Business Review, 16(3), 118-144.

Lee, S. H., Leem, C. S., \& Bae, D. J. (2018). The impact of technology capability, human resources, internationalization, market resources, and customer satisfaction on annual sales growth rates of Korean software firms. Information Technology and Management, 19, 171-184.

Liang, T.-P., \& You, J. J. (2009). Resource-based view in information systems research: A meta-analysis. Proceedings of Pacific Asia Conference on Information Systems 2009.

Li, E. Y., Chen, J., \& Huang, Y. (2006). A framework for investigating the impact of information technology capability and organisational capability on firm performance in the late industrializing context. International Journal of Technology Management, 36(1-3), 209-229.

Lu, Y., \& Ramamurthy, K. (2011). Understanding the link between information technology capability and organisational agility: An empirical examination. MIS Quarterly, 35(4), 931-954. https://doi.org/10.2307/41409967

Macharia, N. W, Mike A. I, Ondabu I., \& Kepha, T, O. (2015). Effects of information technology on performance of logistics firms in Nairobi. Country International Journal of Scientific and Research Publications, 5(4), 23-46.

Mao, H., Liu, S., \& Zhang, J. (2015). How the effects of IT and knowledge capability on organisational agility are contingent on environmental uncertainty and information intensity. Information Development, 31(4), 358-382. https://doi.org/10.1177/0266666913518059

Mavengere, N. B. (2013). Information technology role in supply chain's strategic agility. International Journal of Agile Systems and Management, 6(1), 7-24.

Mazidi, A. R., Amini, A., \& Latifi, M. (2014). The impact of information technology capability on firm performance: A focus on employee customer profit chain. Iranian Journal of Management Studies, 7(1), 95-120. https://doi.org/10.22059/ijms.2014.36204

Michael, S., Storey, D., \& Thomas, H. (2002). Discovery and coordination on strategic management and entrepreneurship. In M. A. Hitt, R. D. Ireland, S. M. Camp, \& D. L. Sexton (Eds.), Strategic Entrepreneurship: Creating a New Mindset (pp. 45-65). Oxford, UK: Blackwell Publishers.

Muscalu, E. (2014). Organisational culture change in the organisation. Land Forces Academy Review, 19(4), 392-412. pdfs.semanticscholar.org

Mwangi, R. W., \& Waithaka, P. (2018). Organisational culture and performance of public universities in Kenya. International Academic Journal of Human Resource and Business Administration, 3(2), 288-313.

Napitupulu, I. H. (2018). Organisation culture in management accounting information system: Survey on State-owned enterprises (SOEs) in Indonesia. Global Business Review, 19(3), 1-16. https://doi.org/10.1177/0972150917713842

Ockley, J. A., Senaji, T. A., \& Kinyanjui, M. (2017). Relationship between organisational factors and performance of insurance brokerage firms in Kenya. International Journal of Human Resource and Business Administration, 2(3), 361-380.

Oliveira, S. R. M. (2017). High radicality of product innovation and high flexibility and high agility of system of manufacturing: Towards the smart factories. Procedia Manufacturing, 11, 1324-1334. https://doi.org/10.1016/j.promfg.2017.07.261.

Onigbinde, I. O. (2014). Evaluation of petroleum products marketing in a globalizing economy: A conceptual evidence from Nigeria. British Journal of Marketing Studies, 2(2), 71-81.

Onobrakpeya, A. S., Nana, O. G., \& Odu, P. E. (2018). Improving service delivery through information and communication technology in the Nigerian manufacturing industry. Apeejay-Journal of Management Sciences and Technology, 5(2), 61-84.

O'Regan, N. (2002). Market share. The conduct to future success? European Business Review, 14(4), 287-293. https://doi.org/10.1108/09555340210434474

Oyerinde, A. J., Olatunji, O. C., \& Adewale, O. A. (2018). Corporate social responsibility and performance of oil and gas industry in Nigeria. EKSU Journal of the Management Scientists, 2(1), 97-106.

Panda, S., \& Rath, S. K. (2016). Investigating the structural linkage between IT capability and organisational agility: A study on Indian financial enterprises. Journal of Enterprise Information Management, 29(5), 
751-773. https://doi.org/10.1108/JEIM-04-2015-0033

Pebrianto, A., \& Djamhur, S. K. (2013). The influence of information technology capability, organisational learning, and knowledge management capability on organisational performance (a study of banking branches' company in Southern Kalimantan province). Information and Knowledge Management, 3(11), 112-120.

Penrose, E. (1959). The theory of the growth of the firm. Oxford: Blackwell.

Philips, R., Freeman, R., \& Wicks, A. C. (2003). What stakeholder theory is not. Business Ethics Quarterly, 13(4), 479-502. https://doi.org/10.5840/beq200313434

PricewaterhouseCoopers (2018). Review of the Nigeria oil and gas industry.

Rahim, F. B. T., \& Zainuddin, Y. B. (2019). The impact of technological innovation capabilities on competitive advantage and firm performance in the automotive industry in Malaysia. AIP Conference Proceedings, 2059(1), 20-30. https://doi.org/10.1063/1.5085973

Rehman, N., Nor, M. N. M., Taha, A. Z., \& Mahmood, S. (2018). Impact of information technology capabilities on firm performance: Understanding the mediating role of corporate entrepreneurship in SMEs. Academy of Entrepreneurship Journal, 24(3), 1-19.

Rubin, I. I. (1973). Essays on Marx's theory of value. Black Rose Books Ltd.

Salehzadeh, R., Pool, J. K., Mohseni, A. M., \& Tahani, G. (2017). Factors influencing organisational performance: The role of knowledge sharing and organisational agility. International Journal of Business Excellence, 11(3), 344-356. https://doi.org/10.1504/IJBEX.2017.081930.

Sampath, J. M. (2015). Exploring the significance of strategic agility in building sustainable competitive advantage for retail banks in India. Working Paper Series No. ST-16-01. SVKM's Narsee Monjee Institute of Management Studies, School of Business Management, Deemed University.

Schein, E. H. (2004). Organisational culture and leadership (Jossey-Bass Business \& Management Series). Jossey Bass Incorporated.

Stafford, D., \& Miles, L. (2013). Integrating cultures after a merger. Bain M\&A (documento de trabajo).

Tabe-Khoshnood, N., \& Nematizadeh, S. (2017). Strategic agility and its impact on the competitive capabilities in Iranian private banks. International Journal of Business and Management, 12(2), 220-229. https://doi.org/10.5539/ijbm.v12n2p220

Tippins, M. J., \& Sohi, R. S. (2003). IT competency and firm performance: is organisational learning a missing link? Strategic Management Journal, 24(8), 745-761. https://doi.org/10.1002/smj.337

Turulja, L., \& Bajgoric. N. (2016). Innovation and information technology capability as antecedents of firms' success. Interdisciplinary Description of Complex Systems, 14(2), 148-156.

Uzkurt, C., Kumar, R., Semih-Kimzan, H., \& Eminoğlu, G. (2013). Role of innovation in the relationship between organisational culture and firm performance: A study of the banking sector in Turkey. European Journal of Innovation Management, 16(1), 92-117. https://doi.org/10.1108/14601061311292878

Wernerfelt, B. (1984). A resource-based view of the firm. Strategic Management Journal, 5(2), 171-180. https://doi.org/10.1002/smj.4250050207

Zafari, H. (2017). Marketing strategies to enhance profitability among international oil and gas service companies. Walden Dissertations and Doctoral Studies.

Zhou, N., Zhang, S., Chen, J., \& Han, X. (2017). The role of information technology (IT) in firms' resource orchestration process: A case analysis of China's "Huangshan 168". International Journal of Information Management, 37(6), 713-715. https://doi.org/10.31063/2073-6517/2019.16-1.5

\section{Copyrights}

Copyright for this article is retained by the author(s), with first publication rights granted to the journal.

This is an open-access article distributed under the terms and conditions of the Creative Commons Attribution license (http://creativecommons.org/licenses/by/4.0/). 